\title{
Shifts in Leaf and Branch Elemental Compositions of Pinus massoniana (Lamb.) Following Three-Year Rainfall Exclusion
}

\author{
Tian Lin ${ }^{1,2}{ }^{\mathbb{D}}$, Xuan Fang ${ }^{1}$, Yongru Lai ${ }^{1}$, Huaizhou Zheng ${ }^{1, *}$ and Jinmao Zhu ${ }^{1}$ \\ 1 Fujian Provincial Key Laboratory of Plant Ecophysiology, Fujian Normal University, Fuzhou 350007, China; \\ lintian0918fjnu@163.com (T.L.); fxuan1992@163.com (X.F.); Yongrulai@163.com (Y.L.); \\ jmzhu@fjnu.edu.cn (J.Z.) \\ 2 College of Ecological Environment and Urban Construction, Fujian University of Technology, \\ Fuzhou 350118, China \\ * Correspondence: zhz@fjnu.edu.cn; Tel.: +86-591-83483731
}

Received: 18 December 2019; Accepted: 13 January 2020; Published: 16 January 2020

\begin{abstract}
We investigated changes in leaf and branch stoichiometry of Pinus massoniana caused by seasonal variation and experimental drought in response to a three-year manipulation of the rainfall exclusion. The results showed that (1) in response to rainfall exclusion manipulation, plant capacity to regulate leaf potassium $(\mathrm{K})$ concentrations were notably lower than for leaf nitrogen $(\mathrm{N})$ and phosphorus (P) concentrations. Thus, the plants modulated leaf $\mathrm{N}$ and $\mathrm{P}$ concentrations to improve water use efficiency, which take part in drought resistance mechanisms. Leaf K concentrations decreased continuously, having additional indirect negative effects on plant fitness. (2) The effects of seasonal variation on both the leaf $\mathrm{K}$ and $\mathrm{P}$ concentrations were significantly stronger than on leaf $\mathrm{N}$ concentrations. High leaf $\mathrm{N}$ and $\mathrm{P}$ concentrations and a low $\mathrm{N}: \mathrm{P}$ ratio in the growing season improved the growth rate. (3) Principal component analyses (PCA) revealed that to adapt to drought, the plants regulated nutrient elements and then maintained certain stoichiometries as a capital to resist stress. Our results suggest that, on nutrient-poor soils, a lack of $\mathrm{N}$ or $\mathrm{P}$ (or both) would probably impede P. massoniana's response to drought.
\end{abstract}

Keywords: drought; rainfall exclusion; nitrogen; phosphorus; potassium; N:P ratio

\section{Introduction}

Global climate change is modifying patterns of global precipitation, leading to changes in the frequency and magnitude of extreme climatic events, such as drought [1,2]. Increased drought enhances tree mortality [3,4] and influences ecosystem biodiversity as well as ecosystem structure and function [5-8]. Several studies have shown that terrestrial plants adapted and resistant to drought can alter their physiological characteristics to increase water use efficiencies to prevent death [9-11]. The elemental composition of a species is determined by long-term genetic adaptation and specific ecological strategies to a particular environment [12], which is associated with responses to environmental stress [13,14]. For example, during long-term drought, element concentrations in different organs of plants change, promoting plant adaptation to drought stress. Therefore, the shift in the elemental composition and stoichiometry of different plant organs can reflect the response of plants to forest drought stress.

The main goal of ecological stoichiometry is to understand the relationships among Carbon, Nitrogen, Phosphorus (C:N:P) ratios in organisms and environments [15]. The C:N:P ratios in organisms can be associated with important ecological processes, such as responses to environmental stress $[13,16]$, ecosystem composition and diversity $[17,18]$. An organism's C:N:P stoichiometry can be influenced 
by the environment through two pathways. First, environmental changes can alter the C:N:P ratios of producers, thereby affecting the growth rate and lifestyle through nutrient cycling [19]. Growth rate hypothesis (GRH) posits that to enhance rapid growth influenced by the intensity of the protein synthesis the organism needs more $\mathrm{P}$, which involves a low N:P ratio. It is responsible for the high growth in the environment [20]. Previous studies on planktonic communities reported that low N:P ratios correlate with high growth rates [6]. Similarly, terrestrial plants with low N:P ratios grow rapidly and are more competitive for soil resources $[15,21]$. However, under normal growth condition, the distributions of the elements in higher plants contribute to the operations of storage, defensive, and anti-stress systems, as well [22]. Many studies reported how foliar stoichiometries vary along environmental gradients [23-25]. All these studies suggested that the main climatic variables (e.g., temperature and precipitation) can influence the actual water content in the plant and intensities of solar radiation arriving at the leaves, which in turn affect foliar elemental stoichiometries.

Leaf elemental compositions and stoichiometries are important in forest research, as they can indicate the nutritional status of soil and the growth rate of plants [6,22], reflecting plant acclimatization to climate change $[23,24]$. However, most studies of plants stoichiometries considered only foliar $\mathrm{N}$ and P; they neglected the other photosynthetic organ, branches, and neglected other elements, as well. The concentrations or ratios of other elements, such as $\mathrm{K}$, magnesium (Mg), and iron (Fe), play more important roles in the physiological functions of organisms [10]. The biogeochemical niche hypothesis, which can reflect species' growth and resources uptake strategies as well as space and time occupation, expresses the main nutrients, such as $\mathrm{C}, \mathrm{N}, \mathrm{P}, \mathrm{K}$, and other essential nutrients, such as calcium $(\mathrm{Ca}), \mathrm{Mg}$, and sulfur (S), in different proportions $[10,22]$. These proportions are called stoichiometrical flexibility in response to environmental changes and competitive situations. For example, Yu et al. [26] showed that species with higher stoichiometrical flexibility tended to have higher concentrations of $\mathrm{N}$ and $\mathrm{P}$ and lower N:P ratios. It is easier to understand and interpret the plant stoichiometric shift in the multivariate space of the contents $\mathrm{N}, \mathrm{P}$, and $\mathrm{K}$ in the plant tissues. The alterations in $\mathrm{N}$ and P levels separately cannot uncover a relevant explanation of this phenomenon [27].

The tissue concentrations of $\mathrm{K}$ are vital in plant biology [28], and particularly in dry environments, because $\mathrm{K}$ levels affect several physiological functions in plants, such as controlling the water content of leaves by stomatal control, cell osmosis equilibrium, and water use efficiency [14,29-31]. Shifts in foliar N:P:K ratios are related to the change in plant response to drought [32]. Some plants in dry environments have a higher concentration of $\mathrm{K}$, which is related to metabolome shifts toward increasing concentrations of metabolites linked to osmosis control; these high levels of $\mathrm{K}$ help the plants to resist drought $[14,16,33]$. The concentrations of $\mathrm{K}, \mathrm{N}$, and $\mathrm{P}$ together help to control water availability $[6,34]$. Drought is also the driving force of the changes in elemental $C$ and C:nutrient ratios, especially $C: N$, $C: P$, and $C: K$ [35]. The published evidence suggests that decreasing water availability in drought conditions differently affects the $\mathrm{N}$ and $\mathrm{P}$ cycles and increases the $\mathrm{C}$ :nutrient ratios in photosynthetic tissues due to increased levels of C-rich compounds, such as phenolics and tannins, to avoid water stress [14]. These are the protective mechanisms associated with slowing growth and increasing leaf $\mathrm{N}: \mathrm{P}$ ratios [32,36]. Many studies identified the relationship between high N:P stoichiometries and low growth rates in terrestrial plants, determined by water availability [19,37]. Rivas-Ubach et al. [34] observed increasing N:P ratios during the dry season along with the decrease in primary metabolism and secondary anti-stress metabolism. The changes of the element concentrations in plant tissues induced by drought can be considered the indicators of plant physiological state alteration. Thus, we intended to map the relationships of the terrestrial plant stoichiometry to environmental changes.

We investigated the effects of drought on the stoichiometries and compositions of photosynthetic organs (leaves and branches). We used a three-year field-simulated drought test that ran from April 2013 until January 2016 in ChangTing County, Fujian province, China (Figure 1). We aimed to provide evidence of different drought sensitivities of on leaf and branch stoichiometry dynamics of mature Pinus massoniana individuals, which are widely used for research in subtropical areas experiencing red soil erosion. We measured leaf and branch $\mathrm{C}, \mathrm{N}, \mathrm{P}$, and $\mathrm{K}$ concentrations and their ratios of $P$. 
massoniana growing in control (natural) conditions and under drought (100\% rainfall exclusion). The main aims of this study were (1) to investigate the changes of leaf and branch stoichiometries of $P$. massoniana in response to three-year 100\% rainfall exclusion, (2) to investigate the seasonal dynamic characteristics in leaf and branch macro-elemental concentration of P. massoniana over the study period, and (3) to investigate which element led to the imbalance of osmotic regulation is the key lethal factor to drought stress.

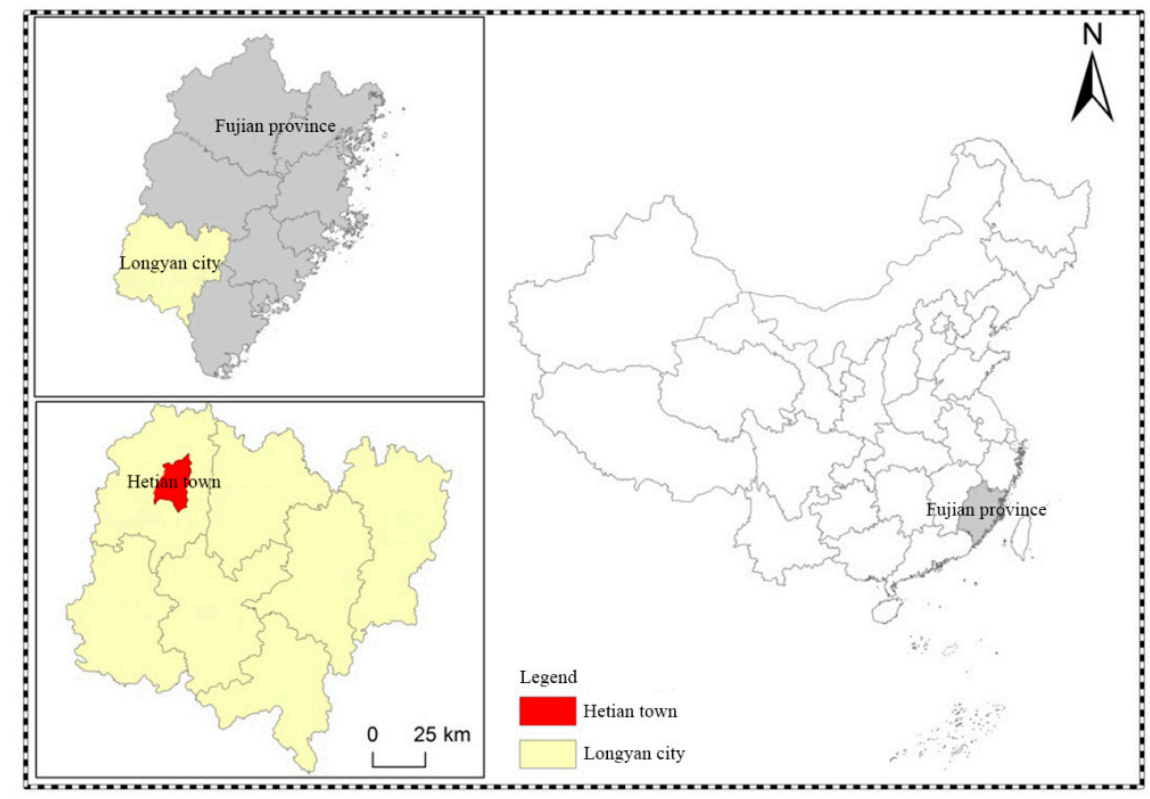

Figure 1. Map of the study area.

\section{Materials and Methods}

\subsection{Study Site}

This study was performed in the town of HeTian, southeast of ChangTing County, Fujian province, China $\left(25^{\circ} 33^{\prime}-25^{\circ} 48^{\prime} \mathrm{N}, 116^{\circ} 18^{\prime}-116^{\circ} 31^{\prime} \mathrm{E}, 310 \mathrm{~m}\right.$ above sea level), which experiences some of the most serious soil erosion in the Fujian province [38]. The main soil type is red soil, which is characterized as nutrient-poor with coarse grain granite parent material. Most of the soil is exposed core, or even bedrock. Because of soil depletion, shrub and grass vegetation is scarce, and the dominant plant species are P. massoniana, Dicranopteris dichotoma (Thunb) Berhn [39]. The integrated mean concentrations of C, $\mathrm{N}, \mathrm{P}$, and $\mathrm{K}$ in soil $(0-30 \mathrm{~cm})$ were $1.06 \mathrm{mg} \cdot \mathrm{g}^{-1}, 0.15 \mathrm{mg} \cdot \mathrm{g}^{-1}, 0.017 \mathrm{mg} \cdot \mathrm{g}^{-1}$, and $4.26 \mathrm{mg} \cdot \mathrm{g}^{-1}$, respectively. The study site belongs to subtropical monsoon climate with the wet seasons typically from March to September and the dry seasons generally from October to February. The study area experienced a mean annual rainfall of $1696 \mathrm{~mm}$ in the study period, and a mean annual temperature of $19.85^{\circ} \mathrm{C}$, with the variation range from $-7.8{ }^{\circ} \mathrm{C}$ to $39.8^{\circ} \mathrm{C}$. Temperature, soil moisture, precipitation, and relative humidity were recorded every $15 \mathrm{~min}$ from the installed automatic weather station (Monitor Automatic Weather Station, ICT, NSW, Australia) at the study site (Figure 2). We used the linear relationship of precipitation and temperature to define aridity conditions. The climate was classified as drought when the temperature was 2-fold greater than the precipitation [40]. The calculated results in Figure 2 show that the arid climate happened when the precipitation point was lower than the temperature. As a result, arid conditions occurred for six months between April 2013 and January 2016: October 2013, January 2014, April 2014, September 2014, October 2014, and October 2015. Hence, we concluded that the study site was not arid, so it was used as a control area. 


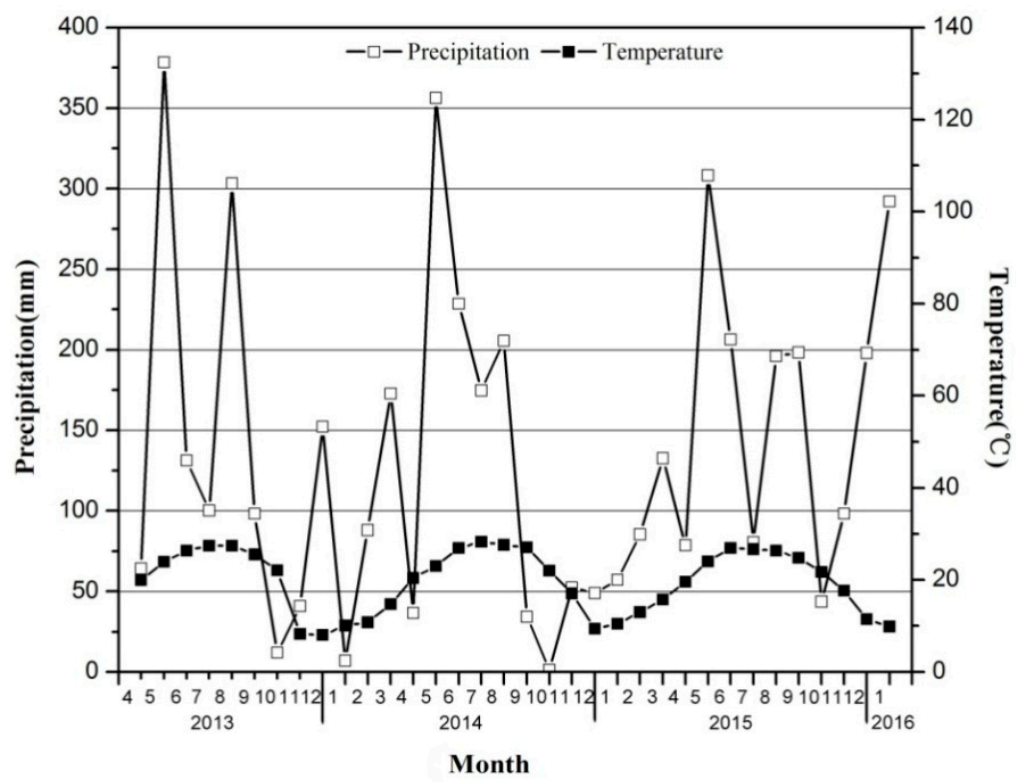

Figure 2. Monthly accumulated precipitation and average temperature from April 2013 to January 2016.

\subsection{Experimental Design}

The experimental setting involved a three-year experiment of $100 \%$ rainfall exclusion. Starting in April 2013, four plots (each $20 \times 20 \mathrm{~m}$ ) of mature P. massoniana were established, on a slope of $30^{\circ}$ at $333 \mathrm{~m}$ above sea level, facing southwest. In each sample plot, there were 10 or 11 mature P. massoniana individuals, which had been sown by plane in 1998. The mean diameter at breast height (DBH) of $P$. massoniana was $4.2 \mathrm{~cm}$, tree height was $2.4 \mathrm{~m}$, and blade length was $8.5 \mathrm{~cm}$ (Figure 3). To avoid the impact of rainwater runoff on sampling, two plots (one upslope and one downslope) subject to $100 \%$ rainfall exclusion as the drought plot, and the other two were influenced by the rainfall events (Figure 4). In the drought plots, a $4 \mathrm{~m}$ transparent wave tile coated with UV paint (light transmittance $90 \%$ ) was fixed above the canopy. To channel the rainfall flow down the slope, wave tiles were installed parallel to the terrain. Polyvinyl chloride (PVC) strips did not have any effects on ambient temperature and humidity. A ditch $80 \mathrm{~cm}$ in depth was dug along the top edge of the drought plots to intercept up-slope runoff, which was channeled to the bottom edge. The remaining plots received no manipulation.
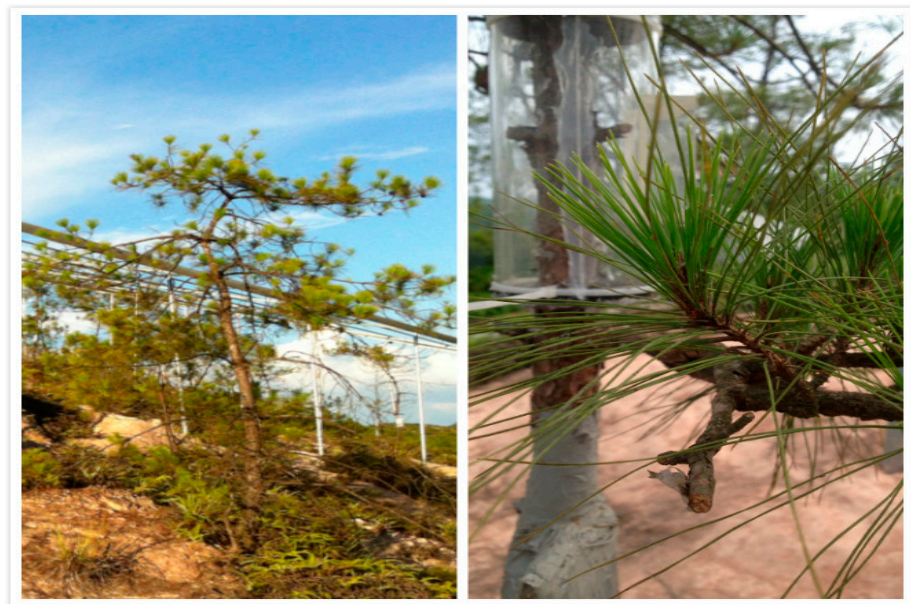

Figure 3. The experimental stand of Pinus massoniana. 


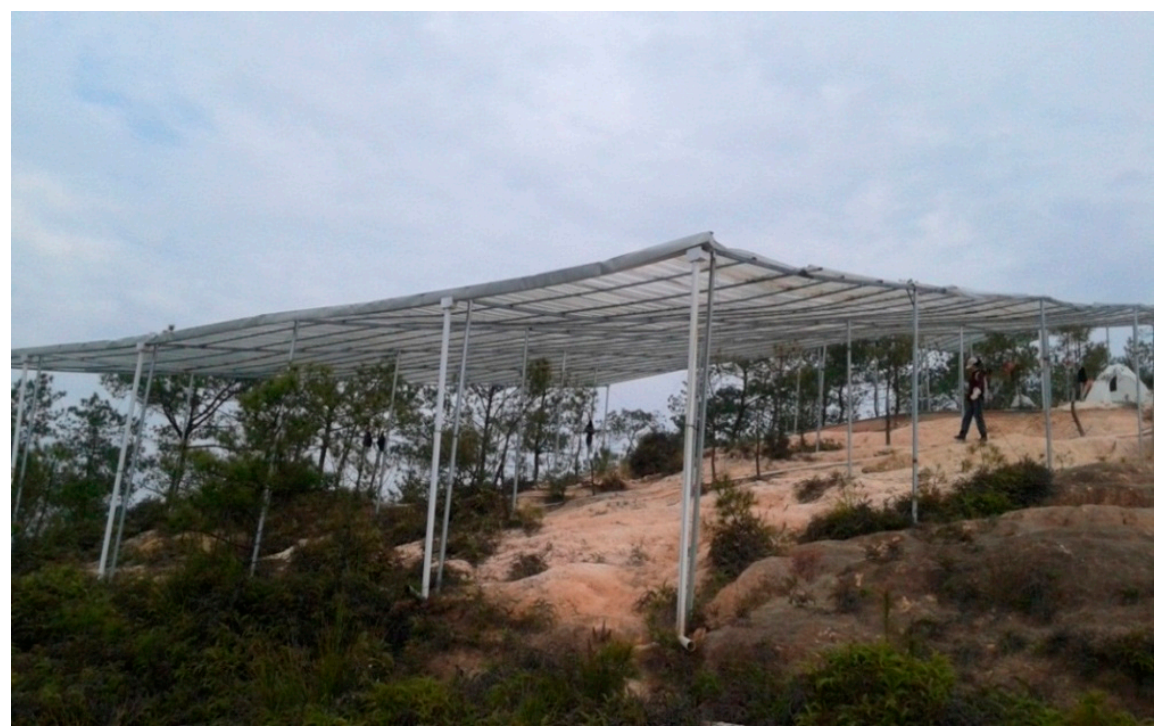

Figure 4. Actual sample plot.

\subsection{Soil Moisture Content}

Using a time-domain soil moisture meter (Trime-T3, Moisture Meter, IMKO, Ettlingen, Germany), soil moisture content at depths of 20 and $80 \mathrm{~cm}$ in the control and drought groups were measured every $15 \mathrm{~min}$.

\subsection{Leaf Water Potential}

Leaf water potentials were measured before dawn ( $\Psi \mathrm{d})$ using a WP4 dew-point potential meter (Decagon Device, Pullman, WA, USA). Three sample trees were chosen from each plot approximately every month from April 2013 to March 2014. We collected two south-facing branches from the top and middle parts of each individual canopy, choosing those with healthy leaves. We immediately put the branches into cold storage $\left(0-4{ }^{\circ} \mathrm{C}\right)$, and brought them to the lab.

\subsection{Sampling Method}

After 115 days of rainfall exclusion, to avoid boundary effects, 6 randomly selected individuals ( 3 from the upslope and 3 from the downslope plot) were selected from the center of each treatment plot. The date of plant sampling was determined according to the main phenological rhythm of the study area. The specific sampling days were as follows: day 115 (18 August 2013, late summer), day 185 (27 October 2013, autumn), day 256 (6 January 2014, winter), day 332 (23 March 2014, spring), day 467 (1 August 2014, late summer), day 542 (15 October 2014, autumn), day 638 (30 December 2014, winter), day 738 (9 April 2015, spring), day 861 (10 August 2015, late summer), day 941 (29 October 2015, autumn), and day 1032 (28 January 2016, winter).

In the study period, we collected leaf and branch samples from each individual to determine elemental concentrations. To avoid the effects of diurnal variation, four small branches exposed to sunlight were consistently selected from the top and middle parts of each crown, both southeast- and northwest-facing, between 09:00 and 11:00 a.m. Well-developed leaves were collected above the branch samples. The leaf lengths ranged from 8.3 to $8.6 \mathrm{~cm}$, and the branch diameters (with bark removed) ranged from 0.3 to $0.5 \mathrm{~cm}$, which were treated as one leaf sample and one branch sample, respectively. Before laboratory analysis, all samples were placed in cold storage $\left(0-4{ }^{\circ} \mathrm{C}\right)$. To reduce enzymatic activity, all samples were microwave-treated at $800 \mathrm{~W}$ for $5 \mathrm{~min}$ and then dried at $65{ }^{\circ} \mathrm{C}$ for $48 \mathrm{~h}$ until the weight became constant [41]. The samples of leaves and branches were ball-milled into a fine powder (Tissuelyser-24, Shanghai, China) for measuring C, N, P, and K. 


\subsection{Elemental Analyses}

To analyze $\mathrm{C}$ and $\mathrm{N}$ concentrations, 9-11 $\mathrm{mg}$ of the powders from each sample was wrapped in tin foil for analysis. The $\mathrm{C}$ and $\mathrm{N}$ concentrations were determined using a $\mathrm{CN}$ elemental analyzer (ElementarVario ELIII, München, Germany).

The plant samples were digested by a $\mathrm{HNO}_{3} \cdot \mathrm{H}_{2} \mathrm{O}_{2}$ mixed system. Firstly, $100 \mathrm{mg}$ dry plant powder was accurately weighed and placed in $50 \mathrm{~mL}$ disposable fluorinated ethylene-propylene (FEP) digestion tubes, which are suitable for graphite digestion systems and are characterized by direct volume fixing, which prevents errors in transfer. Then, $8 \mathrm{~mL}$ pure $\mathrm{HNO}_{3}($ Merck GR $2.5 \mathrm{~L})$ was slowly added along the pipe wall, and finally, $2 \mathrm{~mL} \mathrm{H}_{2} \mathrm{O}_{2}$ was added for overnight treatment. On the second day, after gently shaking the tube, gradient heating digestion in graphite furnace was conducted as follows: temperature increased to $80^{\circ} \mathrm{C}$ and maintained for $10 \mathrm{~min}$, and then maintained for $30 \mathrm{~min}$ at $100{ }^{\circ} \mathrm{C}$, with continuous heating to $110^{\circ} \mathrm{C}$ until thick white smoke was emitted. The final solution was concentrated to 1-2 mL. After cooling, the solution was directly fixed in a fluorinated ethylene-propylene (FEP) tube with a deionizing solution, filtered with a 0.45 microporous membrane, and then placed in the refrigerator for testing.

P concentrations were determined using a continuous flow analyzer (SKALAR SAN++, Breda, Netherlands), and K concentrations were determined using a flame spectrophotometer (Aopu PF640, Shanghai, China). Plant C, N, P, and K concentrations are expressed as $\mathrm{mg} \mathrm{g}^{-1}$ on a dry weight basis.

\subsection{Statistical Analyses}

All statistical analyses were performed using SPSS 19.0 software (SPSS Inc., Chicago, IL, USA). All results are reported as mean \pm standard deviation (SD) for the six replicates of each treatment. To study the different treatments and seasonality effects, we analyzed data using a general linear model. A repeat measure analysis was used to analyze the effects of different treatments on the element concentrations and ratios. To detect patterns of sample ordination with element concentrations and ratios on seasons and drought, the data were subjected to principal component analysis (PCA). We conducted PCA analyses using all elemental concentrations and important nutrient ratios and selected those that had the highest loading on the main axes. PCA axes were used to detect differences among leaves and branches of different seasons or between control and drought plots. Figures were all drawn using Origin 8.0 software and Canoco 5.0.

\section{Results}

\subsection{Soil Moisture Content and Leaf Water Potential}

The initial soil moisture contents in the control group $(24.59 \%$ at $20 \mathrm{~cm}$ and $36.37 \%$ at $80 \mathrm{~cm})$ were similar to the drought group $(23.05 \%$ at $20 \mathrm{~cm}$ and $36.47 \%$ at $80 \mathrm{~cm})$. In the study period, the soil moisture contents in the drought group decreased continuously. The average soil moisture contents at $20 \mathrm{~cm}$ (mean 10.69\%) and $80 \mathrm{~cm}$ (mean 17.31\%) of the drought group were both significantly lower than the corresponding soil moisture at $20 \mathrm{~cm}$ (mean $22.56 \%$,) and $80 \mathrm{~cm}$ (mean 30.85\%) in the control group $(p<0.01$; Figure 5). The decreasing amplitudes were $11.87 \%$ and $13.54 \%$, respectively. In this regard, the average soil moisture content in the drought group seems to meet the needs for normal metabolism, and the average soil moisture content decreased by $10 \%-20 \%$ over the study period, which is only defined as mild drought [42]. We tried to explain that $100 \%$ rainfall exclusion could only simulate mild drought for the following reasons: (1) groundwater flow caused by moderate slope and (2) stomatal closure of the water stress mechanism initiated by P. massoniana. Mild drought was probably a better representation of the real scenario expected under natural conditions in the southeastern coastal areas of China. However, soil moisture contents of 20 and $80 \mathrm{~cm}$ depths in the control group presented significant seasonal fluctuations ( $p<0.01$; Figure 5). 


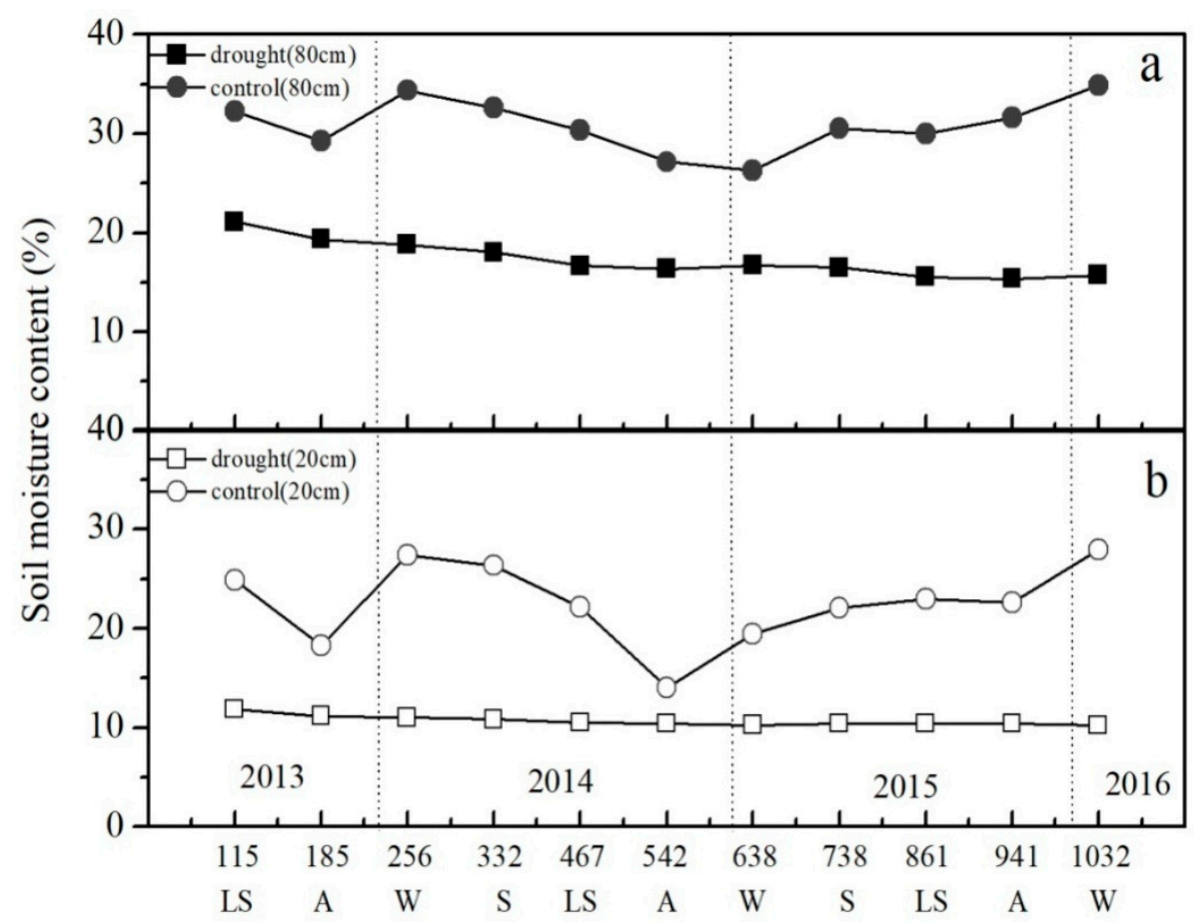

Figure 5. Relativechanges in soil moisture content across the study period (from April 2013 to January 2016) in the control and drought plots. Samples were collected in later summer (LS), autumn (A), winter (W), and late spring (S). (a) Soil moisture content at $80 \mathrm{~cm}$ in the control and drought plots; (b) Soil moisture content at $20 \mathrm{~cm}$ in the control and drought plots.

Then, we determined the leaf water potential of P. massoniana to test the effects of rainfall exclusion from April 2013 to March 2014. Continuous drought stress led $\Psi \mathrm{d}$ in the drought group to decrease over the study course. The average value of the drought group ( $\Psi \mathrm{d}:-3.73 \mathrm{MPa})$ was significantly lower than that of the control group ( $\Psi \mathrm{d}:-2.80 \mathrm{MPa}, p<0.05$ ) (Figure 6), indicating that differences in soil water could be experienced between the treatments. To further confirm these findings, the correlation between leaf water potential and soil moisture content in different treatments were analyzed. In the control group, we found no significant correlation in the 20 or $80 \mathrm{~cm}$ soil layers under normal water supply conditions. Leaf water potential was only affected by abiotic factors. The leaf water potential in the drought group was significantly positively correlated in the $20 \mathrm{~cm}$ soil layer $\left(\Psi \mathrm{d}=0.077 \mathrm{smc}^{2}\right.$ $\left.-2.012 \mathrm{smc}+8.813 R^{2}=0.95286, p<0.01\right)$ and positively correlated in the $80 \mathrm{~cm}$ soil layer $(\Psi \mathrm{d}=-0.009$ $\left.\mathrm{smc}^{2}+0.577 \mathrm{smc}-11.995 R^{2}=0.816, p<0.05\right)$. These results showed that when the soil moisture content was limited, the root water uptake of $P$. massoniana could not meet the needs of transpiration, and leaf water potential decreased with decreasing soil moisture content.

\subsection{Effect of Drought Stress on Element Concentrations}

The 100\% rainfall exclusion resulted in a general increase in leaf $\mathrm{N}$ and $\mathrm{P}$ concentrations over the course of the studied years of $10.88 \%$ and $2.81 \%$, respectively (Figure 7 ). Leaf $\mathrm{N}$ and $\mathrm{P}$ concentrations shared a common characteristic: leaf $\mathrm{N}$ and $\mathrm{P}$ concentrations between the control group and the drought group were not statistically different during the early stage of the 1032 days of study (Figure 7). Then, in the later periods, leaf $\mathrm{N}$ and $\mathrm{P}$ concentrations in the drought group were significantly higher than in the control group $(p<0.05)$, at $23.6 \%$ and $10.4 \%$, respectively. Changes appeared on days 542-638 and 467-542 for $\mathrm{N}$ and $\mathrm{P}$, respectively (Figure 7). In the simulated drought plots, leaf $\mathrm{K}$ concentrations significantly reduced by $14.1 \%(p<0.05)$ (Figure 7). Except for day 638, leaf K concentrations in the drought group were all lower than in the control group. We found no significant change in leaf $C$ concentrations. Changes in the concentration of individual elements also contributed to the differences in their ratios. The effects of rainfall decreased leaf C:N $(p<0.05)$ ratio and increased leaf N:P $(p<0.05)$, 
$\mathrm{N}: \mathrm{K}(p<0.01)$, and P:K $(p<0.01)$ ratios. Leaf N:P ratios were similar to $\mathrm{N}$ and P concentrations; after divergence on days 542-638, leaf N:P ratios in the drought group (Table 1) were significantly higher than in the control group.

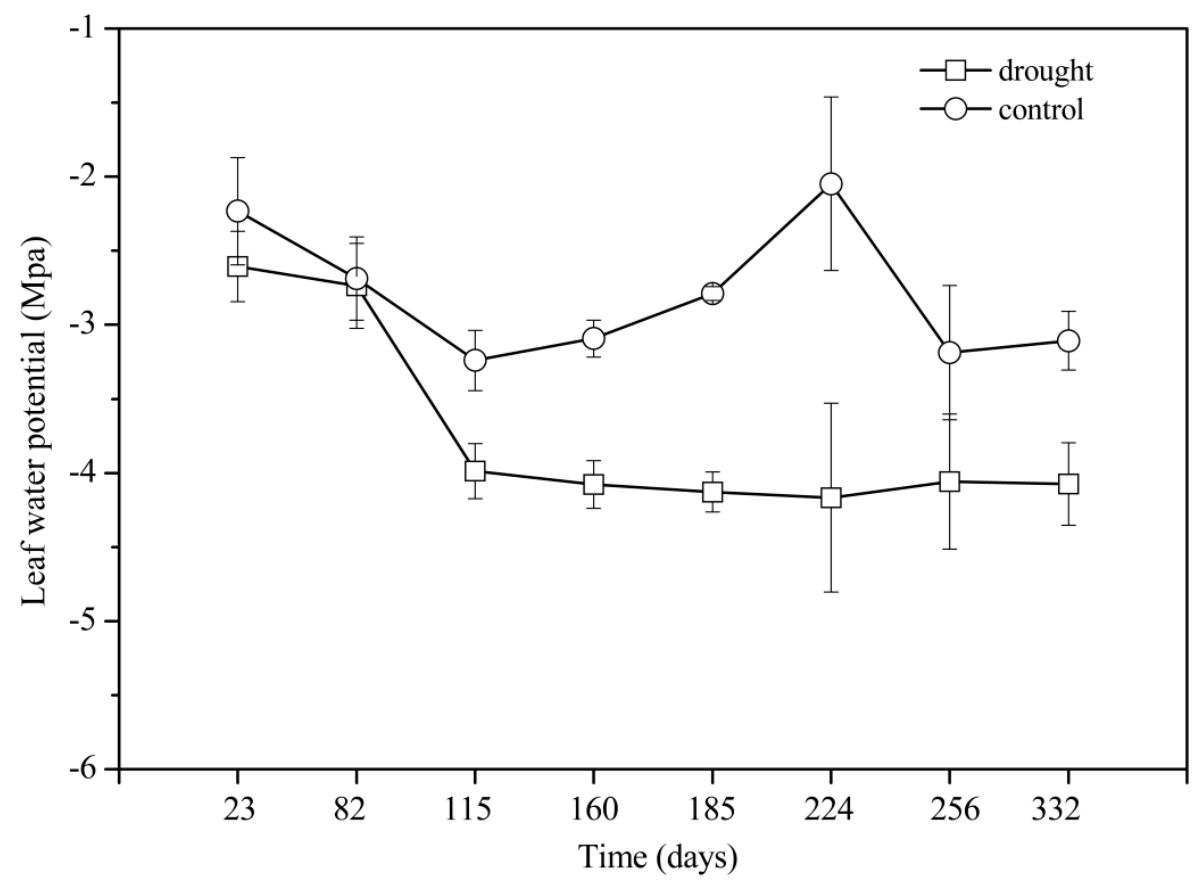

Figure 6. Monthly variation of dawn leaf water potentials between April 2013 and March 2014 (mean \pm SD).

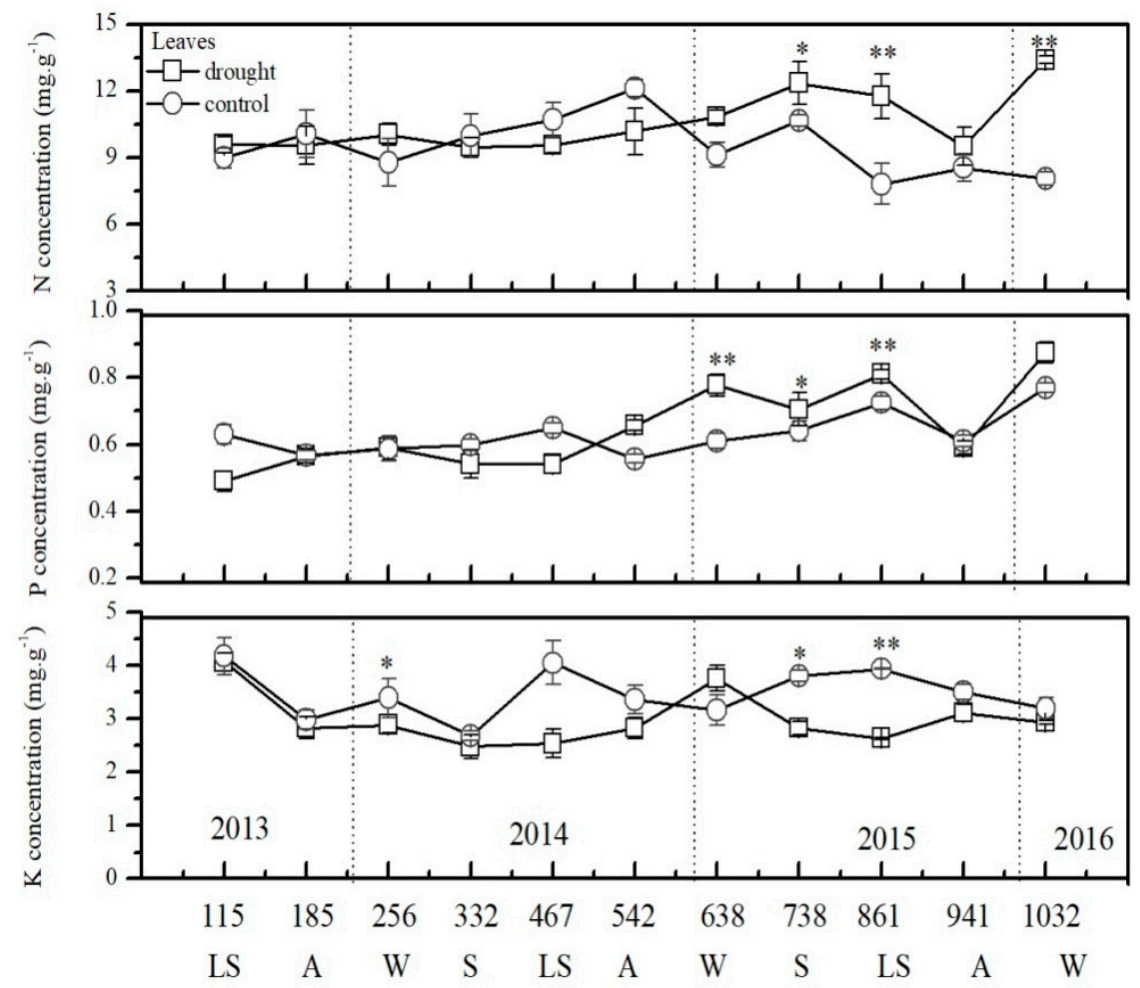

Figure 7. Leaf elemental concentrations of $\mathrm{N}, \mathrm{P}$, and $\mathrm{K}$ in $\mathrm{P}$. massoniana under control and drought treatments (mean $\pm \mathrm{SD}$ ). Samples were selected in late summer $(\mathrm{LS})$, autumn $(\mathrm{A})$, winter $(\mathrm{W})$, and late spring (S) from 2013 to 2016. Different letters indicate significant differences between the control and drought plots; ${ }^{* *} p<0.01,{ }^{*} p<0.05$. 
Table 1. Mean (Standard Deviation, SD) of leaf C: N: P: K ratios of different treatments during the study period.

\begin{tabular}{|c|c|c|c|c|c|c|c|c|c|c|c|c|}
\hline \multirow{2}{*}{ Element Ratio } & Day & 115 & 185 & 256 & 332 & 467 & 542 & 638 & 738 & 861 & 941 & 1032 \\
\hline & \multicolumn{5}{|c|}{ Treatment } & \multicolumn{3}{|c|}{ Mean (SD) } & & & & \\
\hline \multirow{2}{*}{ C:N } & drought & $\begin{array}{l}52.27 \\
(1.84)\end{array}$ & $\begin{array}{l}51.81 \\
(4.71)\end{array}$ & $\begin{array}{l}49.65 \\
(2.19)\end{array}$ & $\begin{array}{l}53.38 \\
(2.44)\end{array}$ & $\begin{array}{l}54.24 \\
(3.5)\end{array}$ & $\begin{array}{l}49.48 \\
(4.25)\end{array}$ & $\begin{array}{l}48.11 \\
(2.26)\end{array}$ & $\begin{array}{l}39.82 \\
(2.07)\end{array}$ & $\begin{array}{l}42.63 \\
(3.25)\end{array}$ & $\begin{array}{l}52.43 \\
(5.00)\end{array}$ & $\begin{array}{l}37.47 \\
(0.49)\end{array}$ \\
\hline & ol & $\begin{array}{l}62.47 \\
(2.47)\end{array}$ & $\begin{array}{l}49.76 \\
(6.77)\end{array}$ & $\begin{array}{l}57.28 \\
(3.33)\end{array}$ & $\begin{array}{l}53.54 \\
(4.95)\end{array}$ & $\begin{array}{l}46.42 \\
(3.97)\end{array}$ & $\begin{array}{l}44.58 \\
(2.37)\end{array}$ & $\begin{array}{l}57.22 \\
(2.79)\end{array}$ & $\begin{array}{l}46.25 \\
(6.72) \\
\end{array}$ & $\begin{array}{l}65.25 \\
(4.12)\end{array}$ & $\begin{array}{l}57.85 \\
(8.47)\end{array}$ & $\begin{array}{l}63.01 \\
(2.44) \\
\end{array}$ \\
\hline \multirow{2}{*}{$\mathrm{N}: \mathrm{P}$} & drought & $\begin{array}{l}12.34 \\
(0.79)\end{array}$ & $\begin{array}{l}16.83 \\
(0.91)\end{array}$ & $\begin{array}{c}17.5 \\
(0.85)\end{array}$ & $\begin{array}{l}17.94 \\
(0.34)\end{array}$ & $\begin{array}{l}17.67 \\
(0.61)\end{array}$ & $\begin{array}{l}15.23 \\
(0.12)\end{array}$ & $\begin{array}{l}16.23 \\
(0.86)\end{array}$ & $\begin{array}{l}18.06 \\
(0.28) \\
\end{array}$ & $\begin{array}{l}14.52 \\
(0.63)\end{array}$ & $\begin{array}{l}16.00 \\
(0.26)\end{array}$ & $\begin{array}{l}15.31 \\
(0.50) \\
\end{array}$ \\
\hline & control & $\begin{array}{c}14.3 \\
(0.56)\end{array}$ & $\begin{array}{c}19.7 \\
(0.78)\end{array}$ & $\begin{array}{l}15.43 \\
(0.62)\end{array}$ & $\begin{array}{l}16.65 \\
(0.58)\end{array}$ & $\begin{array}{l}16.72 \\
(0.56)\end{array}$ & $\begin{array}{c}22.1 \\
(0.58)\end{array}$ & $\begin{array}{l}15.86 \\
(0.42)\end{array}$ & $\begin{array}{l}16.77 \\
(0.46)\end{array}$ & $\begin{array}{l}10.81 \\
(0.41)\end{array}$ & $\begin{array}{c}14.2 \\
(0.68)\end{array}$ & $\begin{array}{l}10.47 \\
(0.77)\end{array}$ \\
\hline \multirow{2}{*}{$\mathrm{N}: \mathrm{K}$} & drought & $\begin{array}{c}2.48 \\
(0.40)\end{array}$ & $\begin{array}{c}3.37 \\
(0.10)\end{array}$ & $\begin{array}{c}3.55 \\
(0.66)\end{array}$ & $\begin{array}{c}3.92 \\
(0.24)\end{array}$ & $\begin{array}{c}3.8 \\
(0.13)\end{array}$ & $\begin{array}{c}3.67 \\
(0.15)\end{array}$ & $\begin{array}{l}3.274 \\
(0.11)\end{array}$ & $\begin{array}{c}4.94 \\
(0.42)\end{array}$ & $\begin{array}{c}4.47 \\
(0.23)\end{array}$ & $\begin{array}{c}3.31 \\
(0.14)\end{array}$ & $\begin{array}{c}4.57 \\
(0.23) \\
\end{array}$ \\
\hline & control & $\begin{array}{c}1.87 \\
(0.02)\end{array}$ & $\begin{array}{c}3.77 \\
(0.23)\end{array}$ & $\begin{array}{c}2.87 \\
(0.16)\end{array}$ & $\begin{array}{c}4.08 \\
(0.07)\end{array}$ & $\begin{array}{c}2.87 \\
(0.06)\end{array}$ & $\begin{array}{c}4.16 \\
(0.29)\end{array}$ & $\begin{array}{c}3.07 \\
(0.33)\end{array}$ & $\begin{array}{c}2.8 \\
(0.17)\end{array}$ & $\begin{array}{c}2.01 \\
(0.28)\end{array}$ & $\begin{array}{c}2.1 \\
(0.02)\end{array}$ & $\begin{array}{c}2.51 \\
(0.05)\end{array}$ \\
\hline \multirow{2}{*}{ P:K } & drought & $\begin{array}{c}0.12 \\
(0.005)\end{array}$ & $\begin{array}{c}0.20 \\
(0.008)\end{array}$ & $\begin{array}{c}0.20 \\
(0.007)\end{array}$ & $\begin{array}{c}0.22 \\
(0.003)\end{array}$ & $\begin{array}{c}0.22 \\
(0.002)\end{array}$ & $\begin{array}{c}0.24 \\
(0.005)\end{array}$ & $\begin{array}{c}0.20 \\
(0.015)\end{array}$ & $\begin{array}{c}0.27 \\
(0.019)\end{array}$ & $\begin{array}{c}0.31 \\
(0.005)\end{array}$ & $\begin{array}{c}0.21 \\
(0.034)\end{array}$ & $\begin{array}{c}0.30 \\
(0.003)\end{array}$ \\
\hline & control & $\begin{array}{c}0.15 \\
(0.017)\end{array}$ & $\begin{array}{c}0.19 \\
(0.008)\end{array}$ & $\begin{array}{c}0.19 \\
(0.003)\end{array}$ & $\begin{array}{c}0.22 \\
(0.005)\end{array}$ & $\begin{array}{c}0.17 \\
(0.003)\end{array}$ & $\begin{array}{c}0.17 \\
(0.002)\end{array}$ & $\begin{array}{c}0.20 \\
(0.002)\end{array}$ & $\begin{array}{c}0.17 \\
(0.003)\end{array}$ & $\begin{array}{c}0.18 \\
(0.004)\end{array}$ & $\begin{array}{c}0.17 \\
(0.009)\end{array}$ & $\begin{array}{c}0.24 \\
(0.004)\end{array}$ \\
\hline
\end{tabular}

Among tissues, for the different treatments, branches in the drought group had similar trends in the changes in leaves, but the changes throughout the whole process were more diverse (Figure 8 , Table 2). Among them, branch $\mathrm{N}$ concentrations and C:N, N:P, N:K ratios showed extremely significant differences $(p<0.01)$, but the other differences were not significant (Figure 8, Table 2).

Table 2. Mean (SD) of branch C: N: P: K ratios of different treatments during the study period.

\begin{tabular}{|c|c|c|c|c|c|c|c|c|c|c|c|c|}
\hline \multirow{2}{*}{ Element Ratio } & Day & 115 & 185 & 256 & 332 & 467 & 542 & 638 & 738 & 861 & 941 & 1032 \\
\hline & \multicolumn{6}{|c|}{ Treatment } & \multicolumn{6}{|c|}{ Mean(SD) } \\
\hline \multirow{2}{*}{$\mathrm{C}: \mathrm{N}$} & drought & $\begin{array}{l}110.77 \\
(5.45)\end{array}$ & $\begin{array}{l}91.81 \\
(7.99)\end{array}$ & $\begin{array}{l}99.02 \\
(3.55)\end{array}$ & $\begin{array}{l}103.1 \\
(10.38)\end{array}$ & $\begin{array}{c}88.6 \\
(0.54)\end{array}$ & $\begin{array}{l}92.59 \\
(9.03)\end{array}$ & $\begin{array}{l}96.43 \\
(11.77)\end{array}$ & $\begin{array}{l}91.56 \\
(10.39)\end{array}$ & $\begin{array}{l}79.81 \\
(7.39)\end{array}$ & $\begin{array}{l}113.38 \\
(4.11)\end{array}$ & $\begin{array}{l}85.74 \\
(4.27)\end{array}$ \\
\hline & ol & $\begin{array}{l}122.39 \\
(1.53)\end{array}$ & $\begin{array}{l}112.03 \\
(12.41)\end{array}$ & $\begin{array}{l}120.68 \\
(6.53)\end{array}$ & $\begin{array}{l}122.98 \\
(7.53)\end{array}$ & $\begin{array}{l}92.38 \\
(5.99)\end{array}$ & $\begin{array}{l}110.75 \\
(10.73)\end{array}$ & $\begin{array}{l}100.88 \\
(9.18)\end{array}$ & $\begin{array}{l}100.5 \\
(8.78)\end{array}$ & $\begin{array}{l}105.53 \\
(8.53)\end{array}$ & $\begin{array}{l}109.05 \\
(4.16)\end{array}$ & $\begin{array}{l}100.3 \\
(6.21)\end{array}$ \\
\hline \multirow{2}{*}{$\mathrm{N}: \mathrm{P}$} & drought & $\begin{array}{l}11.48 \\
(0.54)\end{array}$ & $\begin{array}{l}13.14 \\
(0.28)\end{array}$ & $\begin{array}{l}11.03 \\
(0.29)\end{array}$ & $\begin{array}{l}10.96 \\
(0.58)\end{array}$ & $\begin{array}{l}11.19 \\
(0.53)\end{array}$ & $\begin{array}{l}11.95 \\
(0.47)\end{array}$ & $\begin{array}{c}9.59 \\
(0.76)\end{array}$ & $\begin{array}{l}12.22 \\
(0.17) \\
\end{array}$ & $\begin{array}{c}11.7 \\
(0.21) \\
\end{array}$ & $\begin{array}{l}11.52 \\
(0.67) \\
\end{array}$ & $\begin{array}{l}13.27 \\
(0.34) \\
\end{array}$ \\
\hline & control & $\begin{array}{c}13.6 \\
(0.31)\end{array}$ & $\begin{array}{c}8.35 \\
(0.43)\end{array}$ & $\begin{array}{l}10.48 \\
(0.93)\end{array}$ & $\begin{array}{l}12.43 \\
(0.48)\end{array}$ & $\begin{array}{l}12.48 \\
(0.41)\end{array}$ & $\begin{array}{c}9.61 \\
(0.46)\end{array}$ & $\begin{array}{c}8.65 \\
(0.66)\end{array}$ & $\begin{array}{c}11.2 \\
(0.65)\end{array}$ & $\begin{array}{l}11.62 \\
(0.41)\end{array}$ & $\begin{array}{l}11.09 \\
(0.42)\end{array}$ & $\begin{array}{c}8.12 \\
(0.32)\end{array}$ \\
\hline \multirow{2}{*}{$\mathrm{N}: \mathrm{K}$} & drought & $\begin{array}{c}1.52 \\
(0.15) \\
\end{array}$ & $\begin{array}{c}2.54 \\
(0.18)\end{array}$ & $\begin{array}{c}2.39 \\
(0.14)\end{array}$ & $\begin{array}{c}2.43 \\
(0.11) \\
\end{array}$ & $\begin{array}{c}1.82 \\
(0.09) \\
\end{array}$ & $\begin{array}{c}2.25 \\
(0.12)\end{array}$ & $\begin{array}{c}2.24 \\
(0.14) \\
\end{array}$ & $\begin{array}{c}2.04 \\
(0.04)\end{array}$ & $\begin{array}{c}3.32 \\
(0.20)\end{array}$ & $\begin{array}{c}3.75 \\
(0.24) \\
\end{array}$ & $\begin{array}{c}2.63 \\
(0.19)\end{array}$ \\
\hline & control & $\begin{array}{c}1.44 \\
(0.12)\end{array}$ & $\begin{array}{c}1.73 \\
(0.03)\end{array}$ & $\begin{array}{c}2.03 \\
(0.44)\end{array}$ & $\begin{array}{c}1.92 \\
(0.14)\end{array}$ & $\begin{array}{c}1.85 \\
(0.15)\end{array}$ & $\begin{array}{c}1.62 \\
(0.23)\end{array}$ & $\begin{array}{c}1.97 \\
(0.09)\end{array}$ & $\begin{array}{c}1.82 \\
(0.16)\end{array}$ & $\begin{array}{c}2.03 \\
(0.11)\end{array}$ & $\begin{array}{c}2.12 \\
(0.11)\end{array}$ & $\begin{array}{c}2.41 \\
(0.15)\end{array}$ \\
\hline \multirow{2}{*}{$\mathrm{P}: \mathrm{K}$} & drought & $\begin{array}{c}0.13 \\
(0.030)\end{array}$ & $\begin{array}{c}0.2 \\
(0.051)\end{array}$ & $\begin{array}{c}0.21 \\
(0.027)\end{array}$ & $\begin{array}{c}0.22 \\
(0.003)\end{array}$ & $\begin{array}{c}0.16 \\
(0.066)\end{array}$ & $\begin{array}{c}0.19 \\
(0.017)\end{array}$ & $\begin{array}{c}0.23 \\
(0.014)\end{array}$ & $\begin{array}{c}0.17 \\
(0.011)\end{array}$ & $\begin{array}{c}0.28 \\
(0.008)\end{array}$ & $\begin{array}{l}0.227 \\
(0.014)\end{array}$ & $\begin{array}{l}0.198 \\
(0.012)\end{array}$ \\
\hline & control & $\begin{array}{c}0.11 \\
(0.008)\end{array}$ & $\begin{array}{c}0.21 \\
(0.017)\end{array}$ & $\begin{array}{c}0.19 \\
(0.013)\end{array}$ & $\begin{array}{c}0.17 \\
(0.005)\end{array}$ & $\begin{array}{c}0.15 \\
(0.016)\end{array}$ & $\begin{array}{c}0.17 \\
(0.014)\end{array}$ & $\begin{array}{c}0.23 \\
(0.021)\end{array}$ & $\begin{array}{c}0.16 \\
(0.007)\end{array}$ & $\begin{array}{c}0.17 \\
(0.013)\end{array}$ & $\begin{array}{c}0.19 \\
(0.012)\end{array}$ & $\begin{array}{c}0.29 \\
(0.016)\end{array}$ \\
\hline
\end{tabular}




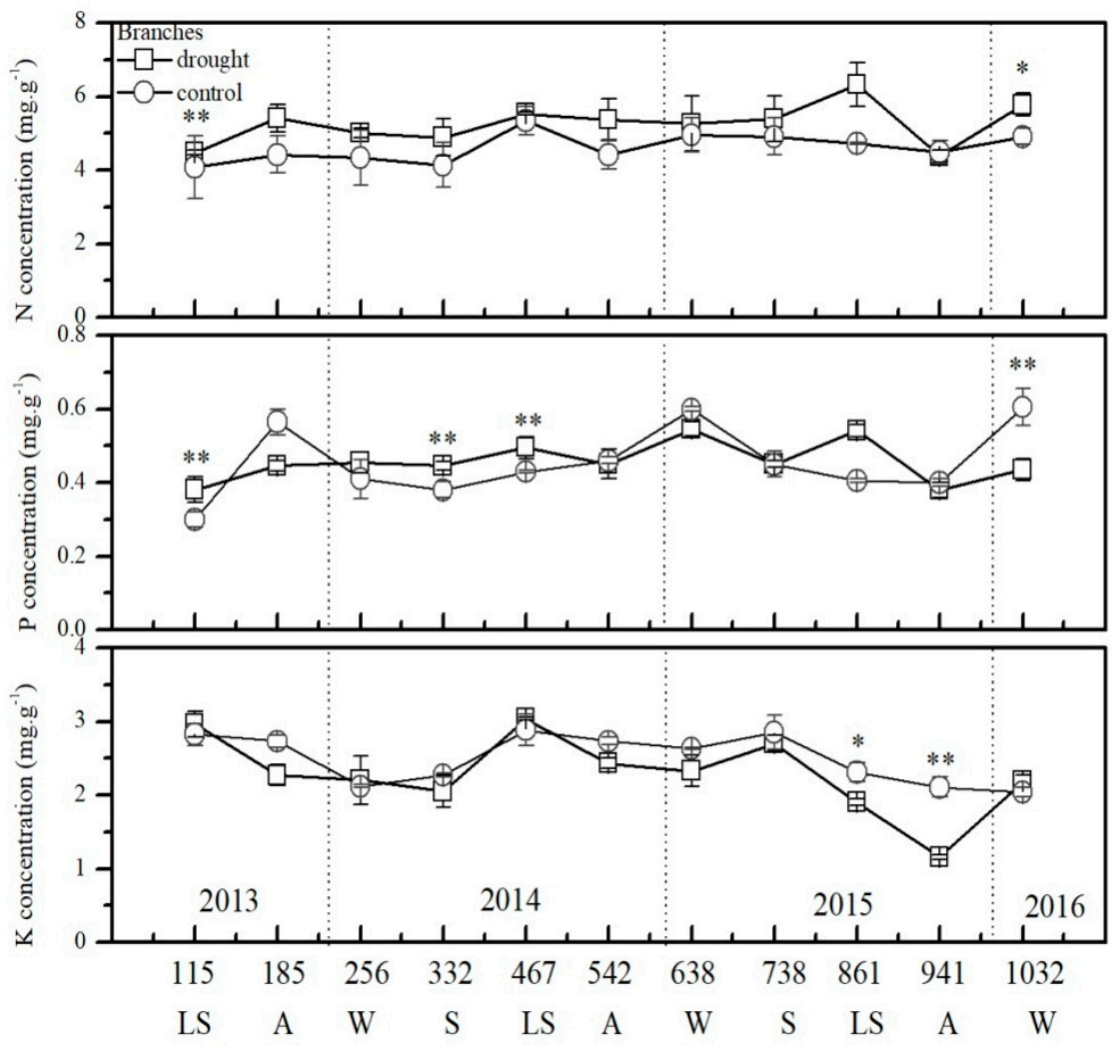

Figure 8. Branch elemental concentrations of $\mathrm{N}, \mathrm{P}$, and $\mathrm{K}$ in P. massoniana under control and drought treatments (mean $\pm \mathrm{SD}$ ). Samples were selected in late summer (LS), autumn (A), winter (W), and late spring (S) from 2013 to 2016. Different letters indicate significant differences between the control and the drought plots; ${ }^{* *} p<0.01,{ }^{*} p<0.05$.

\subsection{Effect of Season on Concentrations of Elements}

In the control group, the concentrations of $\mathrm{N}, \mathrm{P}$, and $\mathrm{K}$ in leaves showed obvious seasonal dynamics during the study period (Figure 7). In 2013 and 2014, from spring through summer to autumn, leaf $\mathrm{N}$ concentrations showed a gradual upward trend in the growing season. The peak value of leaf $\mathrm{N}$ concentrations in these two years appeared on day 185 (27 October 2013, autumn) and day 542 (15 October2014, autumn) at $10.07 \mathrm{mg} \cdot \mathrm{g}^{-1}$ and $12.12 \mathrm{mg} \cdot \mathrm{g}^{-1}$, respectively (Figure 7). These two days were also the minima for the soil moisture contents at both depths (Figure 5). However, the seasonal dynamics in 2015 were different from the previous two years (Figure 7); the peak value appeared

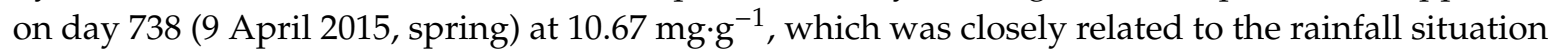
(Figure 2). Leaf P concentrations and K concentrations were the highest in summer from 2013 to 2016. The peak value appeared on day 115 (18 August 2013, late summer), day 467 (1 August 2014, late summer), and day 861 (1 August 2014, late summer) (Figure 5). Leaf N:P ratios were the highest in autumn in 2013 and 2014, but in spring in 2015 (Table 1). Leaf N:K and P:K ratios were the lowest in summer, leaf C:N ratios were the lowest in autumn from 2013 to 2014, but in 2015, C:N ratios were lower in spring (Table 1). We further analyzed the relationship between leaf $\mathrm{N}$ and $\mathrm{P}$ concentrations and N:P ratios. The leaf N:P ratios were significantly positively correlated with leaf $\mathrm{N}$ concentrations $\left(R^{2}=0.8658, p<0.05\right)$ and were significantly negatively correlated with leaf $\mathrm{P}$ concentrations $\left(R^{2}=\right.$ $0.7012, p<0.05)$. When leaf $\mathrm{P}$ concentrations increased more than $\mathrm{N}$ concentrations, leaves had lower $\mathrm{N}: \mathrm{P}$ ratios.

For branches, $\mathrm{C}, \mathrm{N}, \mathrm{P}$, and $\mathrm{K}$ concentrations and $\mathrm{C}: \mathrm{N}, \mathrm{N}: \mathrm{P}, \mathrm{N}: \mathrm{K}$, and $\mathrm{P}: \mathrm{K}$ ratios of the control group changed more diversely than in the leaves. Although we observed certain seasonal dynamics, the annual peak appeared in different seasons during the study period. Then analyzing the branches in 
the drought group, we found that both the elements and ratios follow a consistent trend with leaves in the drought group (Figures 7 and 8, Table 2).

\subsection{Overall Effects of Drought and Season on Leaf and Branch Nutrient Concentrations}

\subsubsection{Leaf Nutrient Concentrations}

PCA revealed that all concentrations of elements and their ratios generally varied in the drought and control groups. Plants at different sampling times in different treatment groups were separated along the principal component 1 (PC1) axis. In our study, we only used leaf C, N, P, and K concentrations and leaf $C: N, N: P, N: K$, and $P: K$ ratios in different treatments as variables. In the drought group, leaf $N$, $\mathrm{P}$ concentrations and C:N ratios were the most important factors (highest loading) in PC1 (Figure 9a), showing that leaf $\mathrm{N}$ and $\mathrm{P}$ concentrations increased and $\mathrm{K}$ concentrations decreased over the course of the drought. PCA was able to distinguish between leaves collected at different sampling points on the PC1 axis, which explained $70.26 \%$ of the overall variance (Figure $9 \mathrm{~b}$ ), which also expressed the sampling times with longer drought duration that were separated from the shorter duration drought except on day 941.
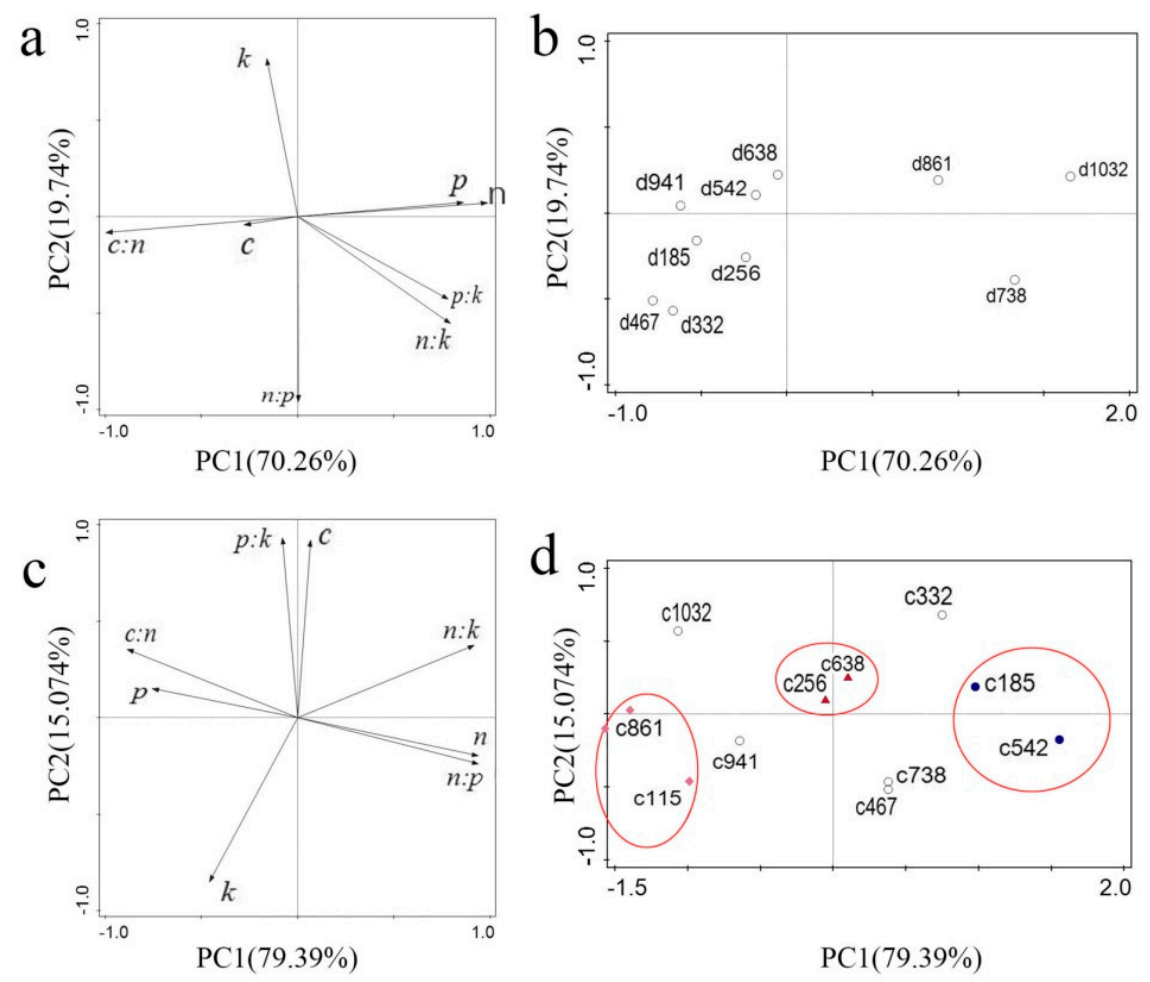

Figure 9. Principal component analysis (PCA) with leaf element concentrations and ratios as variables, and the corresponding variable distribution in (a) and (b) the drought group and (c) and (d) the control group. The significant differences among scores of different sample times are depicted along the PC axes. Note: d256 = day 256 in the drought group; c256 = day 256 in the control group.

In the control group, some of the same seasons were distributed closely, as marked by red circles in Figure $9 \mathrm{~d}$ and separated along PC1 (explaining 79.39\% of the total variance), with leaf $\mathrm{N}$ and P concentrations as the main factors (Figure 9c). The results highlighted the negative correlation between the leaf N:P ratios and P concentrations (Figure 9c). Parts of the same seasons were assigned to the same area; the smaller the score distance between in the PCA space, the more similar to the seasonality of the above indicators of leaves. In the drought group, after the three-year 100\% rainfall exclusion experiments, the impact of seasonal changes completely disappeared. 


\subsubsection{Branch Nutrient Concentrations}

PCA did not provide effective conclusions for the eight selected indexes for branches in the drought group (Figure 10), which suggests that different tissues have different drought adaptation strategies. In the control group, we were unable to obtain useful information from the PCA.
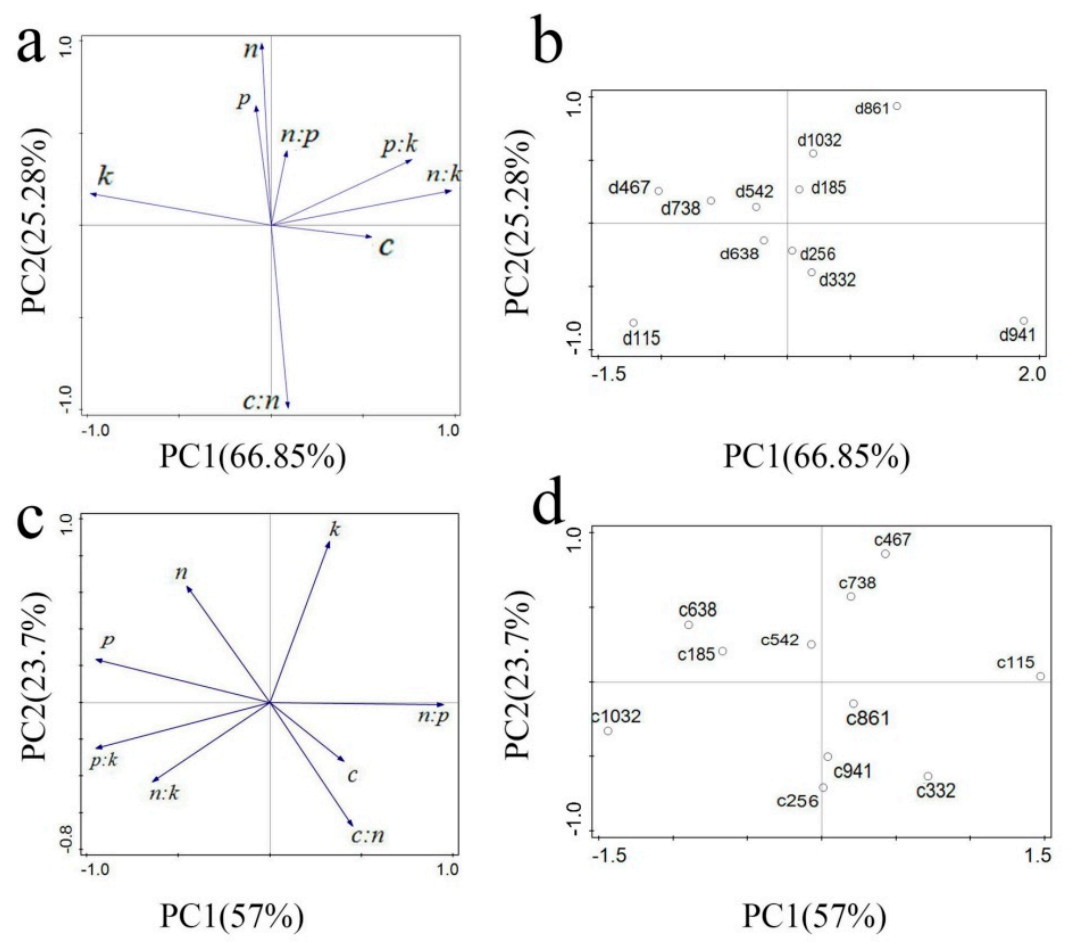

Figure 10. PCA with branch element concentrations and ratios as variables, and the corresponding variable distribution in (a) and (b) the drought group and (c) and (d) the control group. The significant differences among scores of different sample times are depicted along the PC axes. Note: d256 = day 256 in the drought group; c256 = day 256 in the control group.

\section{Discussion}

\subsection{Drought Effect on Nutrient Concentrations}

Using PCA, we identified higher leaf $\mathrm{N}$ and $\mathrm{P}$ concentrations and lower leaf $\mathrm{K}$ concentration under water stress. Plants, especially those adapted to harsh environments, usually respond to stress by altering their nutrient storage [16]. Many studies have reported that leaf $\mathrm{N}$ concentrations in plants increase due to a decrease in water supply $[43,44]$, which is consistent with our findings. In the absence of water, plant water use tends to be more efficient [45]. Increased leaf $\mathrm{N}$ concentrations help plants to achieve maximum photosynthetic volume with minimal moisture content under minimal stomatal conductance [43]. Further increased leaf $P$ concentrations could improve water use efficiency as a drought-resistance mechanism, which has also been widely reported [32,46,47], indicating the positive effects of $\mathrm{P}$ on plant growth under drought stress, such as an increase in root growth [48], stomatal conductance and nitrate reductase activity [49], and high cell-membrane permeability [50]. Similar to leaf $\mathrm{N}$ concentrations, increasing leaf $\mathrm{P}$ concentrations improve photosynthetic efficiency and plant transpiration control capacity [51]. Leaf and branch N:P ratios in the drought group were higher than those in the control group, related to the decrease in growth rate under the condition of lacking water and to the anti-stress mechanism strongly influencing N:P ratio, as plants in anti-stress environments needed higher nutritional investment [14].

Potassium accordingly played a fundamental role under water stress conditions. Most studies suggested that $\mathrm{K}$ concentration increases under drought conditions, which could reduce the osmotic 
potential of cells, improve the water retention capacity of the cell protoplasm, and enhance the stability of the cell membrane [14,29-31]. Adequate K could help improve water use efficiency (WUE) and hence, plant growth under the water deficiency condition [52]. However, in this study, we found that with increasing water stress, leaf and branch $\mathrm{K}$ concentrations decreased considerably, which might lead to the imbalance of osmotic pressure and mineral element concentrations. Concentrations of C, N, and P underwent the self-regulation in the three-year course of $100 \%$ isolation from rainfall, with concentrations increasing to adapt to drought conditions, but concentrations of $\mathrm{K}$ could not self-regulate. K cannot be synthesized in plant cells; most of it must be absorbed or transferred from the soil [25]. As the transport of $\mathrm{K}$ mainly occurs through diffusion, and water is an important factor controlling the diffusion of $K$, loss of water halts the diffusion. Therefore, we think that the imbalance in osmotic regulation caused by the decrease in $\mathrm{K}$ maybe the main reason for the death of $P$. massoniana due to water shortage.

\subsection{Seasonal Variation in Element Concentrations}

The concentrations of $\mathrm{N}, \mathrm{P}$, and $\mathrm{K}$ in leaves of P. massoniana are closely related to their own structural characteristics and growth rhythm, which all change with the seasons. In the control group, the seasonal variation trend of leaf $P$ concentrations in $P$. massoniana during the 1032 days was consistent with the data published by other studies $[24,53,54]$. We observed an obvious upward trend from winter through spring to summer, which then decreased significantly in autumn and increased again from autumn to winter. The reasons behind this trend are as follows: In the early growing season (spring to summer), the photosynthetic organs gradually recovered their normal photosynthetic capacity from low temperature in winter while the plant leaves were small; to organize leaves and grow structural tissue continuously, leaf cells are in the stage of rapid division, which requires large amounts of protein and nuclein. Therefore, the selective absorption of $\mathrm{P}$ increased strengthened, and the concentrations of $\mathrm{P}$ were higher [55]. During the peak growing season (summer to autumn), leaf cells multiply rapidly and expand, so the absorption of nutrient elements by plant roots could not keep pace with the expansion rate of leaf cells, resulting in the gradual dilution of leaf $\mathrm{P}$ concentration [56]. From autumn to winter, after the plant stopped growing, leaf $\mathrm{P}$ concentration in the three-year study period increased by $3.07 \%, 9.51 \%$, and $26,23 \%$ [18]. The seasonal variations in leaf $\mathrm{K}$ concentrations were consistent with those of leaf $\mathrm{P}$, which could be explained using similar reasons. The trend and consistency of the seasonal dynamic change in leaf $\mathrm{N}$ were slightly different from leaf $\mathrm{P}$ and $\mathrm{K}$ concentrations. The peaks in 2013 and 2014 occurred in autumn, and in 2015, the peak occurred in spring. This conclusion is contrary to the findings of other studies, which reported that change process of leaf $\mathrm{N}$ was coordinated with that of leaf $\mathrm{P}$. The analysis showed that P. massoniana, as a pioneer tree species in eroded red soil areas in ChangTing county, have formed their own adaptive mechanism after years of adversity. They reserve as many nitrogen compounds as possible before winter dormancy to resist severe cold and various stress.

Our research supported GRH in the analysis of the effects of seasonal dynamics on leaf $\mathrm{N}$ and $\mathrm{P}$ concentrations and N:P ratios. In the control group, leaf N:P ratios were lowest in spring, summer, and winter from 2013 to 2016 and highest in autumn. The lowest leaf N:P ratios occurred in spring and summer [57], which was consistent with the GRH predictions. This indicates that plants often have high leaf $\mathrm{N}$ and $\mathrm{P}$ concentrations and with low N:P ratio in the growing season to maximize the growth rate capacity $[16,24]$. The reduction in leaf N:P ratios in the winter is not associated with growth rate, but with the effect of the temperature [23]. With decreasing temperature, leaf $\mathrm{N}$ concentrations of plants are basically unchanged, $\mathrm{P}$ concentrations increase, and the N:P ratios decrease $[24,53,54]$. Because at low temperature, plants might activate a temperature-sensitive mechanism that increases leaf $\mathrm{P}$ concentration, thus, improving the enzyme efficiency and reducing the rate of RNA synthesis [23]. As a non-photosynthetic organ, the $\mathrm{N}$ and $\mathrm{P}$ concentrations in branches did not change significantly with the season, so the seasonal variations in branch N:P ratios were inconsistent. 


\subsection{Effects of Soil Nutrient Availability}

The relationship between $\mathrm{N}$ and $\mathrm{P}$ concentrations in plants was determined by soil nutrient conditions and the plasticity of the plants [58]. Many studies generally reported that the leaf N:P ratio could be used as an indicator of soil nutrient deficit; $\mathrm{N}: \mathrm{P}<14$ or N:P $>16$ were used to indicate $\mathrm{N}$ restrictions or $\mathrm{P}$ restrictions, respectively [23,56,59]. However, these results were more common in humid areas. These results areas where water is severely deficient are lacking [60]. Our sample plot had red soil that differentially develops from coarse grain granite and characterized by poor nutrient levels and lack of water, which reduce the availability of $\mathrm{N}$ and $\mathrm{P}$ in the soil [60]. Our results confirm this conclusion. The average concentration of leaf $\mathrm{N}$ in the control group was $9.87 \pm 1.35$ $\mathrm{mg} \cdot \mathrm{g}^{-1}$, and the leaf $\mathrm{P}$ concentration was $0.65 \pm 0.063 \mathrm{mg} \cdot \mathrm{g}^{-1}$. Both were significantly lower than for terrestrial plants globally $\left(\mathrm{N}: 20.1 \pm 8.7 \mathrm{mg} \cdot \mathrm{g}^{-1}, \mathrm{P}: 1.8 \pm 1.1 \mathrm{mg} \cdot \mathrm{g}^{-1}\right)[15,23]$. Because the decrease in soil moisture limits the process of organic matter production and mineralization, the release of $P$ from parent material slowed down, soil organic matter concentration reduced, which was consistent with the availability of $\mathrm{N}$ [61]. When the concentration of leaf $\mathrm{P}$ decreased more than that of leaf $\mathrm{N}$ concentration in the drought group, the average $\mathrm{N}: \mathrm{P}$ value was $15.73 \pm 3.31$, which is significantly higher than that of terrestrial plants globally and, similar to that of desert plants in China [62,63]. Plant $\mathrm{P}$ concentrations were closely related to soil $\mathrm{P}$ concentration. The concentration of soil $\mathrm{P}$ in most parts of China [53] is lower than the global level, which directly affects the P absorbed by plants.

\section{Conclusions}

In summary, we conducted a continuous study to analyze the element dynamics of P. massoniana induced by three-year rainfall exclusion. In the drought group, leaf $\mathrm{N}$ and $\mathrm{P}$ concentrations increased to improve water use efficiency as a drought resistance mechanism. However, leaf K concentrations decreased continuously and were not regulated in response to water stress, which may be the main reason for death due to water shortages. The changes in elements in leaves and branches produced by ontogeny and seasonality were significantly greater than by experimental drought. In the growing season, high leaf $\mathrm{N}$ and $\mathrm{P}$ concentrations and low N:P ratios were consistent with the GRH prediction. Leaf $\mathrm{N}$ concentrations were highest when the soil moisture content was lowest in the annual cycle. Thus, leaves and branches can regulate the nutrient elements and then maintain certain stoichiometries as a method to adapt to stress. Therefore, our findings suggest that in red soil erosion, a lack of $\mathrm{N}$ or $\mathrm{P}$ (or both) would probably impede P. massoniana's response to drought, and therefore, one would expect drought-related dieback to occur earlier.

Author Contributions: T.L., H.Z., and J.Z. designed the experiment. T.L. and H.Z. conducted the field experiment. T.L., X.F., and Y.L. conducted the biochemical analyses in the laboratory. T.L. analyzed data and wrote the manuscript. T.L. and H.Z. revised and improved the manuscript. All authors have read and agreed to the published version of the manuscript.

Funding: This research was funded by the National Nature Science Foundation of China (General Program: 31270659), the Educational Research Projects for Young and Mid-Aged Teachers in Fujian Province of China (Grant NO. JT180333), the Natural Science Foundation of Fujian Province (2018J05011).

Acknowledgments: This research was supported by We thank W.-Y.L. and X.-H.Z. for their assistance in the field and laboratory.

Conflicts of Interest: The authors declare no conflict of interest.

\section{References}

1. Yan, W.; Zhong, Y.; Shangguan, Z. Responses of different physiological parameter thresholds to soil water availability in four plant species during prolonged drought. Agric. For. Meteorol. 2017, 247, 311-319. [CrossRef]

2. Babst, F.; Bouriaud, O.; Poulter, B.; Trouet, V.; Girardin, M.P.; Frank, D.C. Twentieth century redistribution in climatic drivers of global tree growth. Sci. Adv. 2019, 5, eaat4313. [CrossRef] [PubMed] 
3. Allen, C.D.; Macalady, A.K.; Chenchouni, H.; Bachelet, D.; McDowell, N.; Vennetier, M.; Kitzberger, T.; Rigling, A.; Breshears, D.D.; Hogg, E.H.; et al. A global overview of drought and heat-induced tree mortality reveals emerging climate change risks for forests. For. Ecol. Manag. 2010, 259, 660-684. [CrossRef]

4. Galiano, L.; Martinez-Vilalta, J.; Sabate, S.; Lloret, F. Determinants of drought effects on crown condition and their relationship with depletion of carbon reserves in a mediterranean holm oak forest. Tree Physiol. 2012, 32, 478-489. [CrossRef] [PubMed]

5. Anderegg, W.R.L.; Anderegg, L.D.L. Hydraulic and carbohydrate changes in experimental drought-induced mortality of saplings in two conifer species. Tree Physiol. 2013, 33, 252-260. [CrossRef] [PubMed]

6. Peñuelas, J.; Marino, G.; Llusia, J.; Morfopoulos, C.; Farré-Armengol, G.; Filella, I. Photochemical reflectance index as an indirect estimator of foliar isoprenoid emissions at the ecosystem level. Nat. Commun. 2013, 4, 2604. [CrossRef]

7. Knapp, A.K.; Ciais, P.; Smith, M.D. Reconciling inconsistencies in precipitation-productivity relationships: Implications for climate change. New Phytol. 2017, 214, 41-47. [CrossRef]

8. González-Villagra, J.; Rodrigues-Salvador, A.; Nunes-Nesi, A.; Cohen, J.D.; Reyes-Díaz, M.M. Age-related mechanism and its relationship with secondary metabolism and abscisic acid in Aristotelia chilensis plants subjected to drought stress. Plant Physiol. Biochem. 2018, 124, 136-145. [CrossRef]

9. He, M.; Dijkstra, F.A. Drought effect on plant nitrogen and phosphorus: A meta-analysis. New Phytol. 2014, 204, 924-931. [CrossRef]

10. Urbina, I.; Sardans, J.; Beierkuhnlein, C.; Jentsch, A.; Backhaus, S.; Grant, K.; Kreyling, J.; Peñuelas, J. Shifts in the elemental composition of plants during a very severe drought. Environ. Exp. Bot. 2015, 111, 63-73. [CrossRef]

11. Jiao, F.; Shi, X.-R.; Han, F.-P.; Yuan, Z.-Y. Increasing aridity, temperature and soil pH induce soil c-n-p imbalance in grasslands. Sci. Rep. 2016, 6, 19601. [CrossRef] [PubMed]

12. Sistla, S.A.; Schimel, J.P. Stoichiometric flexibility as a regulator of carbon and nutrient cycling in terrestrial ecosystems under change. New Phytol. 2012, 196, 68-78. [CrossRef] [PubMed]

13. Woods, H.A.; Makino, W.; Cotner, J.B.; Hobbie, S.E.; Harrison, J.F.; Acharya, K.; Elser, J.J. Temperature and the chemical composition of poikilothermic organisms. Funct. Ecol. 2003, 17, 237-245. [CrossRef]

14. Sardans, J.; Peñuelas, J. The role of plants in the effects of global change on nutrient availability and stoichiometry in the plant-soil system. Plant Physiol. 2012, 160, 1741-1761. [CrossRef] [PubMed]

15. Elser, J.J.; Acharya, K.; Kyle, M.; Cotner, J.; Makino, W.; Markow, T.; Watts, T.; Hobbie, S.; Fagan, W.; Schade, J.; et al. Growth rate-stoichiometry couplings in diverse biota. Ecol. Lett. 2003, 6, 936-943. [CrossRef]

16. Sardans, J.; Rivas-Ubach, A.; Estiarte, M.; Ogaya, R.; Peñuelas, J. Field-simulated droughts affect elemental leaf stoichiometry in mediterranean forests and shrublands. Acta Oecol. 2013, 50, 20-31. [CrossRef]

17. Roem, W.J.; Berendse, F. Soil acidity and nutrient supply ratio as possible factors determining changes in plant species diversity in grassland and heathland communities. Biol. Conserv. 2000, 92, 151-161. [CrossRef]

18. Güsewell, S.; Bailey, K.M.; Roem, W.J.; Bedford, B.L. Nutrient limitation and botanical diversity in wetlands: Can fertilisation raise species richness? Oikos 2005, 109, 71-80. [CrossRef]

19. Elser, J.J.; Bracken, M.E.S.; Cleland, E.E.; Gruner, D.S.; Harpole, W.S.; Hillebrand, H.; Ngai, J.T.; Seabloom, E.W.; Shurin, J.B.; Smith, J.E. Global analysis of nitrogen and phosphorus limitation of primary producers in freshwater, marine and terrestrial ecosystems. Ecol. Lett. 2007, 10, 1135-1142. [CrossRef]

20. Main, T.M.; Dobberfuhl, D.R.; Elser, J.J. N:P stoichiometry and ontogeny of crustacean zooplankton: A test of the growth rate hypothesis. Limnol. Oceanogr. 1997, 42, 1474-1478. [CrossRef]

21. Willby, N.J.; Pulford, I.D.; Flowers, T.H. Tissue nutrient signatures predict herbaceous-wetland community responses to nutrient availability. New Phytol. 2001, 152, 463-481. [CrossRef]

22. Peñuelas, J.; Sardans, J. Elementary factors. Nature 2009, 460, 803-804. [CrossRef] [PubMed]

23. Reich, P.B.; Oleksyn, J. Global patterns of plant leaf $\mathrm{n}$ and $\mathrm{p}$ in relation to temperature and latitude. Proc. Nat. Acad. Sci. USA 2004, 101, 11001-11006. [CrossRef]

24. Kerkhoff, A.J.; Enquist, B.J.; Elser, J.J.; Fagan, W.F. Plant allometry, stoichiometry and the temperature-dependence of primary productivity. Glob. Ecol. Biogeogr. 2005, 14, 585-598. [CrossRef]

25. Wang, M.; Zheng, Q.; Shen, Q.; Guo, S. The critical role of potassium in plant stress response. Int. J. Mol. Sci. 2013, 14, 7370-7390. [CrossRef] [PubMed]

26. Yu, Q.; Elser, J.J.; He, N.; Wu, H.; Chen, Q.; Zhang, G.; Han, X. Stoichiometric homeostasis of vascular plants in the inner mongolia grassland. Oecologia 2011, 166, 1-10. [CrossRef] 
27. Cakmak, I. The role of potassium in alleviating detrimental effects of abiotic stresses in plants. J. Plant Nutr. Soil Sci. 2005, 168, 521-530. [CrossRef]

28. Zheng, S.; Shangguan, Z. Spatial patterns of leaf nutrient traits of the plants in the loess plateau of china. Trees 2007, 21, 357-370. [CrossRef]

29. Babita, M.; Maheswari, M.; Rao, L.M.; Shanker, A.K.; Rao, D.G. Osmotic adjustment, drought tolerance and yield in castor (Ricinus communis L.) hybrids. Environ. Exp. Bot. 2010, 69, 243-249. [CrossRef]

30. Laus, M.N.; Soccio, M.; Trono, D.; Liberatore, M.T.; Pastore, D. Activation of the plant mitochondrial potassium channel by free fatty acids and acyl-coa esters: A possible defence mechanism in the response to hyperosmotic stress. J. Exp. Bot. 2010, 62, 141-154. [CrossRef]

31. Oddo, E.; Inzerillo, S.; La Bella, F.; Grisafi, F.; Salleo, S.; Nardini, A. Short-term effects of potassium fertilization on the hydraulic conductance of Laurus nobilis L. Tree Physiol. 2011, 31, 131-138. [CrossRef] [PubMed]

32. Sardans, J.; Peñuelas, J. Drought changes phosphorus and potassium accumulation patterns in an evergreen mediterranean forest. Funct. Ecol. 2007, 21, 191-201. [CrossRef]

33. Sardans, J.; Peñuelas, J.; Rivas-Ubach, A. Ecological metabolomics: Overview of current developments and future challenges. Chemoecology 2011, 21, 191-225. [CrossRef]

34. Rivas-Ubach, A.; Sardans, J.; Perez-Trujillo, M.; Estiarte, M.; Penuelas, J. Strong relationship between elemental stoichiometry and metabolome in plants. Proc. Nat. Acad. Sci. USA 2012, 109, 4181-4186. [CrossRef]

35. Filella, I.; Peñuelas, J. Partitioning of water and nitrogen in co-occurring mediterranean woody shrub species of different evolutionary history. Oecologia 2003, 137, 51-61. [CrossRef]

36. MatÍas, L.; Castro, J.; Zamora, R. Soil-nutrient availability under a global-change scenario in a mediterranean mountain ecosystem. Glob. Chang. Biol. 2011, 17, 1646-1657. [CrossRef]

37. Niklas, K.J.; Owens, T.; Reich, P.B.; Cobb, E.D. Nitrogen/phosphorus leaf stoichiometry and the scaling of plant growth. Ecol. Lett. 2005, 8, 636-642. [CrossRef]

38. Xie, J.; Guo, J.; Yang, Z.; Huang, Z.; Chen, G.; Yang, Y. Rapid accumulation of carbon on severely eroded red soils through afforestation in subtropical china. For. Ecol. Manag. 2013, 300, 53-59. [CrossRef]

39. Lin, T.; Zheng, H.; Huang, Z.; Wang, J.; Zhu, J. Non-structural carbohydrate dynamics in leaves and branches of Pinusmassoniana (Lamb.) following 3-year rainfall exclusion. Forests 2018, 9, 315. [CrossRef]

40. Bogeat-Triboulot, M.-B.; Brosché, M.; Renaut, J.; Jouve, L.; Le Thiec, D.; Fayyaz, P.; Vinocur, B.; Witters, E.; Laukens, K.; Teichmann, T.; et al. Gradual soil water depletion results in reversible changes of gene expression, protein profiles, ecophysiology, and growth performance in Populus euphratica, a poplar growing in arid regions. Plant Physiol. 2007, 143, 876-892. [CrossRef]

41. Hoch, G.; Popp, M.; Körner, C. Altitudinal increase of mobile carbon pools in Pinus cembra suggests sink limitation of growth at the swisstreeline. OIKOS 2002, 98, 361-374. [CrossRef]

42. Zhang, T.; Cao, Y.; Chen, Y.; Liu, G. Non-structural carbohydrate dynamics in Robinia pseudoacacia saplings under three levels of continuous drought stress. Trees 2015, 29, 1837-1849. [CrossRef]

43. Wright, I.J.; Reich, P.B.; Westoby, M. Strategy shifts in leaf physiology, structure and nutrient content between species of high- and low-rainfall and high- and low-nutrient habitats. Funct. Ecol. 2001, 15, 423-434. [CrossRef]

44. Wei, H.; Wu, B.; Yang, W.; Luo, T. Low rainfall-induced shift in leaf trait relationship within species along a semi-arid sandy land transect in northern china. Plant Biol. 2011, 13, 85-92. [CrossRef] [PubMed]

45. Jamil Mohammad, M.; Zuraiqi, S. Enhancement of yield and nitrogen and water use efficiencies by nitrogen drip-fertigation of garlic. J. Plant Nutr. 2007, 26, 1749-1766. [CrossRef]

46. Graciano, C.; Guiamét, J.J.; Goya, J.F. Impact of nitrogen and phosphorus fertilization on drought responses in eucalyptus grandis seedlings. For. Ecol. Manag. 2005, 212, 40-49. [CrossRef]

47. Brown, K.R.; Courtin, P.J.; Negrave, R.W. Growth, foliar nutrition and $813 \mathrm{c}$ responses of red alder (alnusrubra) to phosphorus additions soon after planting on moist sites. For. Ecol. Manag. 2011, 262, 791-802. [CrossRef]

48. Singh, V.; Pallaghy, C.K.; Singh, D. Phosphorus nutrition and tolerance of cotton to water stress. Field Crops Res. 2006, 96, 199-206. [CrossRef]

49. Oliveira, M.T.; Medeiros, C.D.; Frosi, G.; Santos, M.G. Different mechanisms drive the performance of native and invasive woody species in response to leaf phosphorus supply during periods of drought stress and recovery. Plant Physiol. Biochem. 2014, 82, 66-75. [CrossRef] 
50. Kang, L.Y.; Yue, S.C.; Li, S.Q. Effects of phosphorus application in different soil layers on root growth, yield, and water-use efficiency of winter wheat grown under semi-arid conditions. J. Integr. Agric. 2014, 13, 2028-2039. [CrossRef]

51. Singh, D.K.; Sale, P.W.G.; Pallaghy, C.K.; McKenzie, B.M. Phosphorus concentrations in the leaves of defoliated white clover affect abscisic acid formation and transpiration in drying soil. New Phytol. 2000, 146, 249-259. [CrossRef]

52. Egilla, J.N.; Davies, F.T.; Boutton, T.W. Drought stress influences leaf water content, photosynthesis, and water-use efficiency of hibiscus rosa-sinensis at three potassium concentrations. Photosynthetica 2005, 43, 135-140. [CrossRef]

53. Han, W.; Fang, J.; Guo, D.; Zhang, Y. Leaf nitrogen and phosphorus stoichiometry across 753 terrestrial plant species in china. New Phytol. 2005, 168, 377-385. [CrossRef] [PubMed]

54. Ren, S.J.; Yu, G.R.; Jiang, C.M.; Fang, H.J.; Sun, X.M. Stoichiometric characteristics of leaf carbon, nitrogen, and phosphorus of 102 dominant species in forest ecosystems along the north-south transect of east china. Chin. J. Appl. Ecol. 2012, 23, 581-586. (In Chinese)

55. Sun, S.C.; Chen, L.Z. Leaf nutrient dynamics Quercus liaotungensis in the dongling mountain region. Acta Phytoecol. Sin. 2011, 25, 76-82. (In Chinese)

56. Güsewell, S. N:P ratios in terrestrial plants: Variation and functional significance. New Phytol. 2004, 164, 243-266. [CrossRef]

57. Gorokhova, E. Analysis of nucleic acids in daphnia: Development of methods and ontogenetic variations in rna-DNA content. J. Plankton Res. 2002, 24, 511-522. [CrossRef]

58. Güsewell, S.; Koerselman, W.; Verhoeven, J.T. Biomass N:P ratios as indicators of nutrient limitation for plant populations in wetlands. Ecol. Appl. 2003, 13, 372-384. [CrossRef]

59. Koerselman, W.; Meuleman, A.F.M. The vegetation N:P ratio: A new tool to detect the nature of nutrient limitation. J. Appl. Ecol. 1996, 33, 1441. [CrossRef]

60. Drenovsky, R.E.; Richards, J.H. Critical N:P values: Predicting nutrient deficiencies in desert shrublands. Plant Soil 2004, 259, 59-69. [CrossRef]

61. Schimel, D.S.; Parton, W.J. Microclimatic controls of nitrogen mineralization and nitrification in shortgrass steppe soils. Plant Soil 1986, 93, 347-357. [CrossRef]

62. Li, C.J.; Lei, J.Q.; Xu, X.W.; Tang, Q.L.; Gao, P.; Wang, Y.D. The stoichiometric characteristics of c, n, p for artificial plants and soil in the hinterland of Taklimakan desert. ActaEcol. Sin. 2013, 33, 5760-5767. (In Chinese)

63. He, M.; Zhang, K.; Tan, H.; Hu, R.; Su, J.; Wang, J.; Huang, L.; Zhang, Y.; Li, X. Nutrient levels within leaves, stems, and roots of the xeric species Reaumuria soongoricain relation to geographical, climatic, and soil conditions. Ecol. Evol. 2015, 5, 1494-1503. [CrossRef] [PubMed]

(C) 2020 by the authors. Licensee MDPI, Basel, Switzerland. This article is an open access article distributed under the terms and conditions of the Creative Commons Attribution (CC BY) license (http://creativecommons.org/licenses/by/4.0/). 